\title{
Betwixt and between. The hybrid identity of a South Tyrolean Bersagliere in the 1935- 1936 Italo-Abyssinian War ${ }^{1}$
}

\author{
Markus Wurzer
}

\author{
Original scientific paper \\ UDK 321.013(436.6)“1935/1936“
}

\begin{abstract}
For South Tyrol, annexation by Italy after World War I resulted in significant changes: the Fascist regime attempted to Italianize the territory and its people using various measures. One of them was the obligation of young men to fulfil military service in the Italian army. Thus, for example, Andrä Ralser served in Sicily and was afterward - in 1935 - drafted to fight in the Italo-Abyssinian War. During this period, he kept a war diary. This source provides some insight into the way in which Ralser dealt with his identity at this particular time. This analysis is preceded by a methodological reflection on the manner in which experienced events are conveyed into a diary in general, suggesting that the writer's biography has to be reconstructed in advance. Finally, an investigation into Ralser's identity shows its dynamic, relative, and hybrid character and how - depending on the context - the diarist felt related to different groups such as South Tyroleans, Bersaglieri, Catholics and Europeans. The article analyses the entangled relationships between these linguistic, territorial, military and religious indicators of identification in a colonial context: when and under which circumstances did the diarist experience (or not experience) moments of group identity?
\end{abstract}

Keywords: hybrid identity, Italo-Abyssinian War 1935-1936, South Tyrol, war diary, Orientalism

1 This article is based on Markus Wurzer's diploma thesis: "Nachts hörten wir Hyänen und Schakale heulen." Das Tagebuch eines Südtirolers aus dem Italienisch-abessinischer Krieg 1935-1936, Erfahren - Erinnern - Bewahren, 6, Innsbruck 2016 
For South Tyrol and its German-speaking people, World War I and the subsequent annexation by Italy resulted in significant changes: the Fascist regime changed German toponyms, forbade the use of the German language in education, public administration and the courts and attempted to destroy their culture. The obligation of young German-speaking men to fulfil the military service in the Italian army was an additional measure in this Italianization process. Paradoxically, this was the army their fathers had fought against during the First World War (Steininger 1997; Lechner 2005; Di Michele 2008; Pergher 2012: 101-104).

Andrä Ralser, ${ }^{2}$ who was born in 1911, was one of these young Germanspeaking men. He fulfilled his military service in Sicily. Consequently, 1935, he was one of 1,376 South Tyroleans who were drafted to fight during the outburst of the Italo-Abyssinian War (Ohnewein 2006: 271). During this period, he kept a war diary ${ }^{3}$ In which he recorded his wartime experiences. This source provides an insight into the way in which Ralser dealt with his own identity as a Germanspeaking South Tyrolean while serving in the Italian army. The diary illustrates that Ralser's identity cannot be determined by using the seemingly rigid identification markers such as ethnicity, nationhood or race alone. Concluding that Ralser considered himself German and not Italian is not satisfactory, as there is more to it than that. Depending on where and when he spoke or acted, he felt related to different groups. This means that he established a hybrid identity between these mutually exclusive positions (Bhabha 2000; Stiegler 2015: 115). Therefore, the key interest of this article is to investigate the entangled relationships between these linguistic, territorial, military and religious indicators of identification in a colonial context: When and under which circumstances did the diarist feel (or not feel) moments of group belonging?

First, it would be worthwhile to reflect on the circumstances in which diaries were written and on the question as to how events were expressed therein. These reflections will show that, in order to analyze Ralser's daily writings, it is relevant to know his biography, his duties specific to the war and

2 The name of the diarist is known to the author. However, a pseudonym was used at his family's request. Thus, for the sake of readability his name was replaced by the pseudonym "Andrä Ralser", which is the German version of the name. The Italian is "Andrea Ralser".

3 "Andrä Ralser", War diary, 13 Jun. 1935-2 Apr. 1936, Archive of the South Tyrolean Folklore Museum, Dietenheim. 
the sequence of events in the Italo-Abyssinian War in general. Additionally, the war diary's tradition, form, language, functions and content will be addressed. Finally, the article analyses self and external images that illustrate Ralser's hybrid identity.

\section{Methodological Background}

As historical sources, personal testimonials such as diaries provide access to individual and collective interpretations, evaluations or social knowledge (Schulze 1996: 13). Due to this potential, they have become popular sources for historiographic/cultural investigations into everyday life, experience and mentalities, especially, in recent decades, within the context of the two World Wars. This was accompanied by institutions such as the Archivio Diaristico Nazionale and the Archivio della scrittura popolare, which collect, archive and make diaries equally accessible both to the scholarly community and the general public. ${ }^{4}$ These archives also retain individual diaries, which are related to the Italian campaign against, and the colonial reign over, Abyssinia. A few have already served as the focus of research (Guerrini 1990: 117-123; Labanca 1990: 93-115; Stefani 2003: 33-52; Ghezzi 2006: 91-129; Orlandi Contucci 2011). In any case, a broad field of literature on the use of diaries as sources is now available. In the case of war diaries it is generally accepted that they do not offer direct access to an "authentic" and total experience of war (Buschmann et al. 2001: 15), since 'experience' means, according to Klaus Latzel, the successful interpretation of an event by an individual who lived through this event (1997: 14). During this process of interpretation, personally experienced events must pass through several selection mechanisms. This selection process results in a reduced representation of the described event in a diary. Thus, in a diary an event is not presented in its totality, but rather in a reduced form (Brandauer 2013:246). The filters that influence the perceptions and diary writing of an individual will be approached below.

The first filter is the type of text and the writing process itself. Individuals use diaries both as mnemonic devices to document events and as an outlet to communicate concerns or anxieties. The circumstances of writing are strongly linked to the question of the value of diaries as sources. Historians must consider

${ }^{4}$ Archivio Diaristico Nazionale, http://archiviodiari.org/ (accessed 14 July 2016); Archivio della scrittura popolare, http://fondazione.museostorico.it/index.php/Archivi-ecollezioni/Fondi-e-collezioni/Archivio-della-scrittura-popolare (accessed 14 July 2016). 
several aspects: maintaining a diary underlies the "autonomy of the moment" (Boerner 1969: 60), which means that through its immediate nearness to an event a diary retrospectively lacks life experience. Instead, the writing is influenced by the writer's individual perception and his personal memory. The writing occurs selectively and randomly under time constraints and is limited by the diary's format (with little space to write). Furthermore, the entries do not offer a complete image of the writer's personality. They show particular aspects and thoughts which were deemed important enough to be recorded despite internal or external censorship. Additionally, the validity of the source depends on the question of where the diarist gathered his/her information: either by personal experience or by hearing another's story (Brandauer 2013: 245). Finally, it is important to underscore that the textual quality of the source is highly contingent upon the writing skills and education of the diarist. Due to the addressee of the diary, which is the writer him-/herself, the realization of language stays implicit. Mental leaps and gaps characterize the text. In order to understand the content, contextual knowledge about the diarist and the particular time in which the diary was kept is necessary (Wisthaler 2011: 5-6).

Second, the process of interpretation is determined by six consciousnessdefining factors of the pre-war period, because they shape the human perception. These factors are: generation, gender, socio-economic environment, religion/ideology, linguistic community and political attitude. For example, a 14year old girl from a working class family will acquire completely different war experiences than a 30-year old man from a middle class family, who has to serve in the army. Third, the experience of an individual depends on the event structure of a war, for the simple reason that every experience is the consequence of an event. Such structures can be the experience of trench warfare, the loss of property and/or loved ones or artillery warfare. Finally, the specific wartime duties of an individual determine the specific empirical world surrounding said individual. For example, the wartime experience of an ordinary soldier differs significantly from the experience of a higher-ranking officer (Koselleck 2000: 266272).

Concluding these theoretical-methodological remarks, it is necessary to examine Andrä Ralser's socio-cultural context in the pre-war period and his military posts during the war before analyzing his war diary with regard to his identity. 


\section{Andrä Ralser}

Andrä was born in a small village in the Wipp Valley in the Crownland of Tyrol in 1911, at that time part of the Austro-Hungarian Empire and a borderland facing Italy. His parents were common farmers. They owned fields, where they planted different crops and made hay. In addition, the family owned a horse and several cows, which grazed on their Alpine pasture during the summers. Andrä had an older sister and two younger siblings. ${ }^{5}$ They grew up in a peasant-Christian milieu. Their parental education was strictly Catholic and conservative. Andrä's father saw to this in particular. He was very religious and had an administrative position in the local church, which was a well-attended pilgrimage church. ${ }^{6}$ In addition to religious content, values such as obedience, bravery and endurance were also emphasized in Andrä's education. It is not surprising that the political attitude of his parents was also conservative. His father seemed to be thoroughly attached to Austro-Hungarian Emperor Francis Joseph I. and revered him like a demi-god. ${ }^{7}$

When World War I ended in 1918, Andrä was already seven years old. As of 1915, Italy declared war against Austria-Hungary, his home was situated in the operative zone of the Austro-Hungarian army. According to the family chronicle, the military occupied the family's house in order to shelter men and material. In addition, they requisitioned foodstuffs, working tools and - particularly difficult for the family - the only horse, which was necessary to till the fields (Heiss 1995: 149). Moreover, Andrä's father had to endure all of these events from a great distance. He was drafted by the Austro-Hungarian military to fight on the Italian front. Except for several furloughs, he was gone from May 1915 until April 1918. During this time his wife had to look after the children and manage the farm work on her own. She was assisted by relatives and friends. ${ }^{8}$ At the end of the war, in November 1918, the collapsing Austro-Hungarian army flooded back through the Wipp Valley in order to cross the Brenner Pass (Steininger 2000: 15). On this

\footnotetext{
${ }^{5}$ Record in parish registers of Stilfes on "Andrä Ralser", South Tyrolean Provincial Archives (SLA), Parish Registers, Rolle MA 409, Stilfes, 1-T, 1843-1924, "Ralser Andrä"; "Ralser" Family Chronicle [written by the daughter of "Andrä Ralser" based on the Aufschreibbuch, which was written by Andrä's father], undated, "Ralser" private collection, Bruneck, 26-27, 41, 46; Land register record "Ralser," Sterzing Land Registry.

6 "Ralser" Family Chronicle, 41, 54.

7 Interview with the daughter of "Andrä Ralser" by the author, Bruneck, 4 Apr. 2012

8 Family chronicle "Ralser-Hofes," 48-50; "Aufschreibbuch Ralser," 301.
} 
occasion, the soldiers passed by Ralser's family home. They stole turnips from their fields and wood from their fences to light fires. ${ }^{9}$ Several days later, the Italian army reached the village and took up quarters itself in the family's house. ${ }^{10}$ Andrä's father observed their arrival through the window with tears in his eyes. From his perspective, all of these events meant that the familiar world, represented by the trinity "God, emperor and fatherland", had broken down and left insecurity and anxiety over the future. Finally, the subsequent annexation by Italy resulted in significant changes for the southern part of Tyrol and its Germanspeaking people: the Fascist regime, which ruled in Italy from 1922 until 1943, changed German toponyms, forbade the use of German in education, public affairs and the courts and attempted to destroy their culture (Pergher 2012: 102103). The South Tyrolean population responded to this radical policy both by retreating to the private sphere and by adapting in order to receive socioeconomic services from the Fascist municipal authorities (Überegger 1996: 220). The final step of this Italianization process was the so-called "Option" in 1939, in which South Tyroleans were forced to decide if they wanted to continue their lives in National Socialist Germany as Germans or in Fascist Italy as Italians (Pergher 2009: 17-25; Pallaver 2011: 18, 20).

To return to Ralser and his individual development: already before the end of the First World War, he had already attended the elementary school in his village. Before German was banned in education, Andrä had also attended a convent school in South Tyrol for two years (1923/24 and 1924/25), which he did not finish. This was an important caesura in his biography: for the very first time he was away from home for several weeks and could visit his family only on holidays. Hence, he was troubled by homesickness. ${ }^{11}$ However, his reading and writing skills in German were preserved. During his stay in the convent school he also had to learn Italian also, which he found helpful later. ${ }^{12}$

Italy re-instituted compulsory military service in autumn 1921, which also affected the young German-speaking men of South Tyrol. Protests against this

\footnotetext{
9 "Aufschreibbuch Ralser," 301, 305.

10 Family chronicle "Ralser," 50.

11 Letter from "Andrä Ralser" to his parents, 16 Jan. 1924, "Ralser" Private Collection, Bruneck, Collection 4, Letter 20.

12 "Ralser-Hof" Family Chronicle 52; "Andrä Ralser" school report card for 1923/24 and 1924/25, Archive of Brixen Capuchin Order, Archive Salern F I Nr. 1, Haupt-Katalog (Registrogenerale) des Ser. Sem. Varna, 1-500, "Ralser Andrä".
} 
requirement proved unsuccessful (Verdorfer 1990: 83). When Ralser reached the age of 20 , he was summoned for a medical examination, which he passed..$^{13}$ Immediately after completing the mandatory pre-military course within the Milizia Volontaria per la Sicurezza Nazionale (MVSN), which was the paramilitary militia of the Fascist regime, he was called to Palermo (Sicily) to perform his military service in 1932/1933. He stayed there for the next 18 months and was trained as a Bersagliere, a highly mobile light infantry unit. ${ }^{14}$ His (basic) Italian skills were now helpful in interactions with a foreign environment. Beyond this, his father encouraged him to pragmatically improve his language skills, because they would help Andrä in his civilian life afterward. ${ }^{15}$ This pragmatic perspective on the Italian language was not taken for granted. Not all South Tyroleans who were in Palermo with Andrä were able to speak Italian at a satisfactory level or even showed any interest in the language. Furthermore, based on his parental education, Ralser took the military seriously. In general, the South Tyroleans perceived the Italian army to be apolitical and independent of the Fascist regime. As a consequence, it was possible for them to interpret military service as performance of one's civic duty (Verdorfer 1990: 83-84). Nevertheless, Ralser struggled with the import of his service from time to time. In such cases, his father attempted to offer him a religious interpretation that was meant to provide guidance. In a letter, his father wrote that it should not matter whether someone served in the Italian or other army. In contrast, the only important thing was to fulfil one's civic duty successfully, because that would be rewarded afterward by God's protection and blessing. ${ }^{16}$

After finishing his military service, he stayed at home for a year and a half. Then he was again conscripted into the military in February 1935. As a consequence, he had to join the ranks of the third Bersaglieri regiment. ${ }^{17}$ In the

13 Record in medical examination register on "Andrea Ralser," State Archives of Bolzano (SAB), Behörden der staatlichen Verwaltung und der Justiznach 1919, Militärisches Schriftgut nach 1919, Aushebungslisten, Lista di Leva dei Giovaninatinell'anno 1911, Provincia di Bolzano, "Ralser Andrea".

14 Military register of "Andrea Ralser," SAB, Behörden der staatlichen Verwaltung und der Justiz nach 1919, Militärisches Schriftgut nach 1919, Militärmatrikelblätter und Matrikelbücher, Distretto di Bolzano, Classe 1911.

15 Letter from "Andrä's" father to his brother, 11 Apr. [1933], "Ralser" Private Collection, Bruneck, Collection 1, letter 18.

16 Letter from "Andrä's" father to “Andrä", 16 Jul. 1933, "Ralser" Private Collection, Bruneck, Collection 1, Letter 10.

17 Military register of "Andrea Ralser". 
following June, he and his comrades were shipped across the Mediterranean Sea and through the Suez Canal to Massaua in Eritrea, ${ }^{18}$ which had been an Italian colony since 1890 (Labanca 2007; Calchi Novati 2011; Pergher 2015: 327-337). After intensive preparations, the war against Abyssinia began on October 3, 1935. Ralser and his regiment were in first line of the attack. Parallel to the events in the north, a second front was opened in the south from the Italian colony of Somaliland, which remained a sideshow during the war. Over the following months, Ralser witnessed the war on the northern main front. He took part in the battles of Adigrat, Macallé, Amba Aradam and Maychew. Consequently, he experienced the Italian army's initial successes and its consolidation, the Abyssinian offensive near the end of 1935 and the Italian further advance, which concluded with the conquest of Addis Abeba, the Abyssinian capital, in May 1936 (Mattioli 2005: 84-91). Earlier, in April, Ralser ceased keeping his diary. Why he did so has not, unfortunately, been explained, ${ }^{19}$ although it is known that he was in the military hospital afterward and finally arrived at home in January $1937 .^{20}$

After Andrä rose in rank during his military service in Palermo, he served as a Caporale Maggiore in his regiment. ${ }^{21}$ Within the military hierarchy he was still part of the ordinary troops, but if needed he was able to occupy the function of a Caposquadra (squad leader), which means that he had some limited power of rank at his disposal (Martin 1933: 53). This role and the duties that it entailed - from participating in combat missions and occupying sentry posts to cleaning the military billet and gathering wood and water for the mess - shaped his war experience.

\section{The Diary - Tradition, Form, Language, Functions, and Content}

When Ralser brought his diary back home with him, it was his father who saw to its preservation. He re-bound it, gave it a title ("Diary of Andrä Ralser while serving in the campaign in Abyssinia in 1936-1937") and pasted on a photograph of his son, depicting him writing in his diary in Africa, into the book. Over the following decades, the diary remained at the farm. Near the end of his life, Andrä Ralser delivered his diary together with some collected letters and photographs

\footnotetext{
18 Military register of "Andrea Ralser".

19 “Andrä Ralser", War Diary, 13 Jun. 1935-2 Apr. 1936.

20 Military register of "Andrea Ralser"; Letter from "Andrä Ralser" to this parents, 7 Jan. 1937, "Ralser" Private Collection, Bruneck, Collection 5, Letter 3.

21 Military register of "Andrea Ralser".
} 
to his eldest daughter, who was just about to move away from home after marrying. She brought these personal testimonials to her new home near Bruneck. In 1987, she gave the diary to the South Tyrolean Folklore Museum as a permanent loan, where remains to this day. ${ }^{22}$

Ralser began writing in his small diary in June 1935, when he set off from Livorno, Italy, and stopped maintaining it approximately ten months later in April 1936, after the Battle of Maychew. As to the volume of his diary, he did not make entries constantly over this period. He wrote the most during his journey from Italy to the Eritrean highlands (June to August 1935). Afterward the volume of entries shrank continuously. It was not until February 1936, when the Italian army took back the initiative on the northern front after a phase of stagnation, that this spatial mobility and the associated experience of something new had a stimulating effect. During his journey and during the stages of mobile warfare, Ralser wrote more about exploring his foreign environment, in contrast to periods of idling or trench warfare (Wurzer 2016). But the frequency and intensity of his writing was not only dependent on mobility and the type of warfare. Other factors such as the weather, his mood and the situation around food had an impact as well (Wisthaler 2011: 12).

The diary's content is characterized by dense writing. No space was wasted by the diarist. Based on which utensil was accessible, he used either a pencil or ink to write. Obvious slips of the pen were not erased afterward; they were simply crossed out. ${ }^{23}$ Generally, the entries consisted of short, often fragmentary sentences strung together. Ralser's writing is full of mental leaps and breaks, implicit passages and gaps. ${ }^{24}$ Furthermore, his writing style largely followed the cadence of spoken language. ${ }^{25}$ As to his language, it is noticeable that he wrote in admittedly standard German, but made use of his South Bavarian dialect as well for words connected to the peasant-Christian milieu, and used Italian terms to designates things tied to the military, such as military ranks, commands, units, tactical procedures, etc. Ralser's writing style depended on his mood as well. To a great extent, he was writing dispassionate and sober. Sometimes he registered cynical or critical expressions. This is strongly connected to the functions the diary served for its author: on the one hand, Ralser used it

22 Interview with the daughter of "Andrä Ralser" by the author, Bruneck, 4 Apr. 2012.

23 See, for example, "Andrä Ralser", War diary, 22 Jun. 1935.

24 E.g. see "Andrä Ralser", War Diary, 20 Jun. 1935.

25 E.g. see “Andrä Ralser”, War Diary, 17 Aug. 1935. 
as mnemonic device to document events, while on the other it was an outlet to communicate concerns or anxieties (Wurzer 2016).

In his diary, Ralser wrote about diverse topics. Given one of the booklet's functions, the diarist recorded everything connected to the official military sphere. However, he hardly recorded anything about his free time. Additionally, he wrote a considerable amount about the weather, his food, accommodations and the sanitary situation. This is not surprising, since all of these topics were directly connected to any soldier's well-being. The foreign, African environment and culture were also of great interest to him. At the beginning of the war, perceptions of the Abyssinian enemy, combat, wounds and death found their expression in the diary. In this context, religion became a survival strategy for Ralser. Therefore, he began writing about field masses, religious feasts, etc. (Wurzer 2016).

\section{Hybrid Identity: Trapped Betwixt and Between}

During 1935, Italy shifted an army of approximately 500,000 men to the Horn of Africa (Labanca 2006: 34). According to statistics, one out of every 500 soldiers was a German-speaking South Tyrolean: 1,376 were drafted and 1,118 young men were finally shipped to Eritrea and Somaliland (the others deserted or had to go to Italian Libya). They were posted among 22 different regiments. Ralser and 39 of his countrymen were assigned to the third Bersaglieri regiment (Ohnewein 2006: 269, 272). Moreover, in day-to-day life, Ralser met other men who were from different generations, social classes, Italian regions, its colonies (Somaliland, Eritrea) and minor ethnicities (Slovenian, French, etc.). Furthermore, the Italian armed forces were not a monolithic block, but were rather divided into three branches of the military services: the Askari, who were colonial soldiers forcibly recruited in Eritrea, the MVSN (Fascist militia) and the actual royal armed forces, which consisted of the army, air force and navy. There was some friction between the different branches of the armed forces (Brogini Künzi 2006: 267, 269). Obviously, the diarist found himself in a heterogeneous setting. How did he perceive himself in this challenging context? How did he deal with his identity? In order to approach these questions, it must be stated that identity markers such as ethnicity, nationality and race are not mere innate concepts, but rather strong and powerful perspectives on the world. Through interpretation, representation, identification and categorization, individuals define themselves and perceive others in ethnic, national or racial terms. Ralser also made use of these frames in order to organize his everyday life and to know 
to whom he belonged and to whom he did not. However, groups should not be considered homogenous and self-contained. Rather they must be thought of as variable, dynamic, contextual, fluctuating and - most of all - as events, in which feelings of belonging arise (Brubaker 2010: 34, 36-37, 39-40). Consequently, there will be an examination of when and under which circumstances Ralser felt a high level of group belonging and when it remained absent. Therefore, his diary will be scrutinized for self- and external images which represent these negotiation processes and demonstrate his hybrid identity. It should also be recalled that the diary's language, which was addressed beforehand, represents the hybrid character of his identity as well. Ralser generally wrote in standard German, but also drew on his dialect and the Italian language when certain words were required.

In the first place, based on his biography, Ralser felt a high level of group belonging with the South Tyroleans in Abyssinia. Language, culture and a common history in the former monarchy, then annexation and Italianization provided the ethnic framework for the group, which perceived itself as a community bonded by fate. Its members shared mutual loyalty and were willing to make sacrifices for each other (Eickelpasch 2004: 69). During the Abyssinian campaign, South Tyroleans such as Ralser constantly tried to get in touch with certain countrymen (Steinacher et al. 2006: 92). On such occasions, the group meshed, e.g., by talking about common acquaintances, ${ }^{26}$ sharing and reading German newspapers from home, ${ }^{27}$ and, especially, by doing small favours for one another like ensuring that their colleagues obtained enough supplies or extra coffee, ${ }^{28}$ or by lending each other requisites such as buckets to wash clothes. ${ }^{29}$ Furthermore, group belonging was fostered through collective cooking, since drinking and eating habits are a manifestation of cultural identity (Müns 2010: 14-15). For example, Ralser described that he met with other South Tyroleans in order to cook "Schmarrn", which is a typical Tyrolean dessert. The importance of this ritual is manifested by the fact that the name of this dessert is the only word Ralser underlined in his whole diary.

\footnotetext{
26 Letter from "Andrä Ralser" to his family, 24 Apr. 1935, "Ralser" Private Collection, Bruneck, Collection 2, Letter 8.

27 Photograph "Die Dolomitenlesend am Pass Alagi 1936", "Ralser" Private Collection, Bruneck, Photograph collection, Photograph 51.

28 "Andrä Ralser", War diary, 10 Jul. 1935 and 21 Aug. 1935.

29 "Andrä Ralser", War diary, 23 Aug. 1935.
} 
Additionally, in their perceptions, the South Tyroleans distanced themselves sharply from "the" Italians. As the oral history study by Martha Verdorfer showed, they considered themselves superior in matters of religion, agriculture and military sense of duty. ${ }^{30}$ Ralser indeed shared these attitudes; ${ }^{31}$ nevertheless - due to his military service in Palermo - he was able to differentiate between various Italians: while he described the population of Southern Italy as "dirty" and emotional, ${ }^{32}$ he accorded recognition to some Northern Italians constructing a street in Eritrea in June 1935. ${ }^{33}$

However, the German-speaking South Tyroleans were not a homogenous group among themselves. Evidence for this can be found in several letters, which were exchanged between Andrä Ralser and his brother Kassian in 1933 during their military service in Palermo and Genoa, where Kassian was deployed. It is Andrä's brother who complained more often that the South Tyroleans in his barracks argued all the time. Simultaneously, Kassian differentiated between his fellow countrymen: e.g., while he perceived men from Puster Valley to be hardworking, others from the capital city of South Tyrol, Bolzano, and from Vinschgau Valley, which is in the western part of South Tyrol, where considered lazy, wanton, lavish and rather irreligious. Hence, Kassian avoided them. ${ }^{34}$ In another context, Andrä's brother denied any solidarity with a South Tyrolean after he was kicked by an Italian, because he was from Bolzano. Instead, he thought that the kick would encourage his fellow countryman to comport themselves as he did. ${ }^{35}$

As a consequence of his parenting, religion played a central role in Ralsers's life. The Roman Catholic community constituted another group - apart from ethnic, national or racial frameworks - to which the diarist felt related. His sense of belonging occurred on several occasions, e.g. when he was able to

30 Verdorfer, Zweierlei Faschismus, 53, 84.

31 “Andrä Ralser", War Diary, 18 Aug. 1935, 2 Sept. 1935, 16 Aug. 1935, 26 Aug. 1935 and 10 Aug. 1935.

32 “Andrä Ralser", War Diary, 15 Jun 1935 and 17 Jun 1935.

33 "Andrä Ralser", War Diary, 26 Aug. 1935.

34 Letters from "Kassian Ralser" to "Andrä Ralser", 4 Apr 1933, "Ralser" Private Collection, Bruneck, Collection 1, Letter 11; 15 Apr. 1933 and 28 May 1933, "Ralser" Private Collection, Bruneck, Collection 3, Letters 1 and 2.

35 Letter from "Kassian Ralser" to "Andrä Ralser", 23 Apr. 1933, "Ralser" Private Collection, Bruneck, Collection 3, Letter 3. 
attend field masses and visit churches or see Catholic missions. At the latter, Ralser also met converted Africans, ${ }^{36}$ who were part of the Catholic Church as well. This shows that the Catholic group was neither inwardly homogeneous nor sharply outwardly delimited. Furthermore, Ralser's sense of religious identity was formed by experiences of alterity, e.g. when he met representatives of the Muslim or Coptic faiths. ${ }^{37}$

At the beginning of this section, it was pointed out that the Italian armed forces in Abyssinia were a heterogeneous body: the Askari, Fascist militia and royal army were its three military formations. The latter, the royal army, additionally consisted of a navy, air force and land army. As a soldier of the third Bersaglieri regiment, Ralser was part of the army. Besides the Bersaglieri, the army contained other branches such as the Alpini, who were mountain troops, the Fanteria, who were the common infantry, artillery, etc. These differentiations provided frames for the articulation of Ralser's affiliations in the military sphere. From his standpoint, the Bersaglieri constituted an elite entity of the Italian army. Ralser saw the reason in the arduous drills during military service, which he considered to be the most difficult in the entire army. In a letter he sent home from Palermo, Ralser told his family that one quarter of the men who had started the service with him had to forsake training during the first weeks and were reassigned to other, less challenging military branches, such as the Fanteria. ${ }^{38}$ This belonging was outwardly communicated by the Bersaglieri's typical helmet, decorated with a cock's feather, and its emblem, featuring a grenade, a hunting horn and crossed rifles. Besides an elitist self-perception, the feeling of solidarity between the Bersaglieri was shaped by common experiences within the shared event structure of war: they were rewarded, blamed, punished as a unit, endured the same physical hardships and mourned the same casualties. ${ }^{39}$ Depending on the context in which Ralser functioned, his regiment, battalion, company, platoon or squad were the benchmarks for his identification with "the" Bersaglieri. ${ }^{40}$ The highest level of identification appeared to be with his squad - the smallest

\footnotetext{
36 “Andrä Ralser”, War Diary, 6 Sept. 1935.

37 "Andrä Ralser", War Diary, 4 Aug., 2 Sept. and 6 Sept. 1935.

38 Letter from "Andrä Ralser" to his family, 1 Jun. 1933, "Ralser" Private Collection, Bruneck, Collection 4, Letter 3.

39 “Andrä Ralser", War Diary, 7-10 Oct. 1935, 23 Jul. 1935, 17 Aug. 1935, 16 Nov.-24 Nov. 1935 and 15 Feb. 1936.

40 “Andrä Ralser", War Diary, 25 Dec. 1935-4 Jan. 1936.
} 
military unit consisting only of a small number of men - since he was surrounded by these men in his everyday life. Furthermore, as Caporale Maggiore, Ralser could act as commander and hence be responsible for his comrades. ${ }^{41}$ After all, his identification with the group was only possible for two reasons. First, Ralser's command of the Italian language allowed him to participate in the group's social life. That was not taken for granted. Only 30 percent of the German-speaking South Tyroleans in Africa had similar skills at their disposal (Ohnewein 2006: 271). Second - as already mentioned before - the South Tyroleans perceived the royal army as apolitical and independent of the Fascist regime. As a consequence, it was possible for them to interpret military service as fulfilment of a civic duty (Verdorfer 1990: 83-84).

By contrast, the MVSN was explicitly attached to the Fascist party. Therefore, and perhaps due to his elite self-image as a Bersagliere, Ralser did not feel any camaraderie with the members of this military branch. On the contrary, in his perception they were old, grey men, who did not fight bravely and always suffered many casualties in combat. ${ }^{42}$

With regard to the Askari, there could have been some potential for identification between soldiers from Eritrea (or Somaliland) on the one hand and those from South Tyrol on the other hand: both territories were subjugated by Italy a few decades before; after the Fascist takeover, the Fascists tried to realize their dream of an Impero in these border zones through harsh policies. ${ }^{43}$ Nevertheless, Ralser's diary contains no passages that would suggest any instances of solidarity between the writer and the Askari. Except for one remark, in which the diarist noted that the Africans did not go to war willingly, as he was told on another occasion, ${ }^{44}$ any comments indicating solidarity remained absent. If anything, Ralser perceived them as exotic: he was fascinated by their foreign

41 “Andrä Ralser”, War Diary, 13 Aug. 1935, 1 Nov. 1935.

42 “Andrä Ralser”, War Diary, 3 Sept. 1935, 29 Nov.-10 Dec. 1935 and 10 Feb. 1936.

43 In this context I would like to hint at the unpublished dissertation of Roberta Pergher, "A Tale of Two Borders: Settlement and National Transformation in Libya and South Tyrol under Fascism", Ph.D. dissertation, University of Michigan, 2007. In her current book project, which is entitled "Fascist Borderlands: Nation, Empire and Italy's Settlement Program, 1922-1943" she will also include other Fascist borderlands, http://history.indiana.edu/faculty_staff/faculty/pergher_roberta.html (accessed 13 July 2016).

44 “Andrä Ralser", War Diary, 3 Sept. 1935. 
rituals, weapons (sabre-like swords), language and eating habits. ${ }^{45}$ The potential identification benchmarks were apparently overlaid by his experiences of otherness.

This experience was mainly shaped by the fact that Ralser was European and consequently adopted a European, i.e., colonial, perspective on the African landscape, its flora and fauna, people and their cultures. His diary entries reflect an image of Africa as a fascinating negative image of the Occident, which homogenized heterogeneity and was based on stereotyped presumptions, with a great deal of self-assurance and orientation (Said 1981; Stiegler 2015: 113). These stereotypes had been shaped by illustrated books, reports, newspapers or lectures by his commanders, and absorbed by him long before he had set foot on the African continent. Already two years earlier, during his military service in Sicily, Ralser had perceived the "black continent" as a dirty and stiflingly hot place, where people lived under catastrophic conditions. ${ }^{46}$ Finally, when he landed at the Horn of Africa, he drew on these stereotype templates. Thus, he perceived the Africans living in poor dwellings as wild, primitive and dirty. In contrast, Europe was considered the "hoard of civilization", whereby the attribute "European" became the measuring stick for the assessment of foreign impressions (Eickelpasch et al. 2004: 85-86). This figure of thought found expression in Ralser's diary, where, for example, he used the term "European" to describe buildings, which, in his perception, reflected a civilized and therefore familiar impression. ${ }^{47}$ Finally, Ralser also adopted this colonial perspective in his perception of the Abyssinian soldiers. In contrast to the modern European soldier, the Abyssinians appear in his diary as archaic warriors, who were unaware of how to use modern weapons, such as grenades, ${ }^{48}$ but who were nonetheless also fearless and brave in close combat with their exotic weapons, such as the sabre. ${ }^{49}$

\footnotetext{
45 “Andrä Ralser", War Diary, 4 Jul. 1935 and 11 Sept. 1935.

${ }^{46}$ Letter from "Andrä Ralser" to his father and mother, 3 Jun. 1932, "Ralser" Private Collection, Bruneck, Collection 4, Letter 10.

47 "Andrä Ralser", War Diary, 11 Nov. 1935.

48 "Andrä Ralser", War Diary, 6 Feb. 1936.

49 "Andrä Ralser", War Diary, 22 Jul. 1935 and 28 Sept. 1935.
} 


\section{Bibliography}

BHABHA 2000

Homi Bhabha, Die Verortung der Kultur, Tübingen 2000.

\section{BOERNER 1969}

Peter Boerner, Tagebuch, Stuttgart 1969.

\section{BRANDAUER 2013}

Isabelle Brandauer, "Die Kriegstagebücher der Brüder Erich und Rudolf Mayr: Kriegserfahrungen an der Südwestfront im Vergleich," in: Jenseits des Schützengrabens: Der Erste Weltkrieg im Osten: Erfahrung Wahrnehmung - Kontext, (ed. B. Bachinger and W. Dornik) Veröffentlichungen des Ludwig Boltzmann-Instituts für KriegsfolgenForschung, 14, Innsbruck et al. 2013, 244-265.

\section{BROGINI KÜNZI 2006}

Giulia BroginiKünzi, Italien und der Abessinienkrieg 1935/36:

Kolonialkriegoder Totaler Krieg?, Krieg in der Geschichte, 23, Paderborn 2006.

\section{BRUBAKER 2010}

Rogers Brubaker, "Ethnicity without groups," in: The Ethnicity Reader. Nationalism, Multiculturalism and Migration (eds. M. Guibernau and J. Rex), Cambridge 2010, 33-45.

\section{BUSCHMANN ET AL. 2001}

Nikolaus Buschmann and Horst Carl, "Zugänge zur Erfahrungsgeschichte des Krieges. Forschung, Theorie, Fragestellung" in: Die Erfahrung des Krieges. Erfahrungsgeschichtliche Perspektiven von der Französischen Revolution bis zum Zweiten Weltkrieg (eds. N. Buschmann and H. Carl), Krieg in der Geschichte, 9, Paderborn et al. 2001., 11-26.

\section{CALCHI NOVATI 2011}

Giampaolo Calchi Novati, L'Africa d'Italia. Una storia coloniale e postcoloniale, Frecce, 112, Roma 2011.

\section{MICHELE 2008}

Andrea Di Michele, Die unvollkommene Italianisierung: Politik und Verwaltung in Südtirol 1918-1943, Veröffentlichungen des Südtiroler Landesarchivs, 28, Innsbruck 2008.

EICKELPASCH ET AL. 2004

Rolf Eickelpasch and Claudia Rademacher, Identität, Bielefeld 2004. 
GHEZZI 2006

Carla Ghezzi, "Famiglia, patria e impero: essere donna in colonia," in: I sentieri della ricerca. Rivista di storia contemporanea, 3, Crodo 2006, 91129.

\section{GUERRINI 1990}

Irene Guerrini, "Esotismo, conquista coloniale ed introspezione personale nel diario di un marinaio di leva," in: Materiali di lavoro, 1/2, Rovereto 1990, 117-123.

\section{HEISS 1995}

Hans Heiss, "Andere Fronten. Volksstimmung und Volkserfahrung in Tirol während des Ersten Weltkriegs," in: Tirol und der Erste Weltkrieg, (eds. K. Eisterer and R. Steininger), Innsbrucker Forschungen zur Zeitgeschichte, 12, Innsbruck et al. 1995, 139-178.

\section{KOSELLECK 2000}

Reinhart Koselleck, Zeitschichten: Studien zur Historik, Frankfurt am Main 2000.

\section{LABANCA 1990}

Nicola Labanca, "Coscritti in colonia. Appunti in tema di percezione dell'Africa e scrittura popolare," in: Materiali di lavoro, 1/2, Rovereto 1990, 93-115.

\section{LABANCA 2006}

Nicola Labanca, "Erinnerungskultur, Forschung und Historiografie zum Abessinienkrieg," in: Zwischen Duce und Negus. Südtirol und der Abessinienkrieg 1935-1941 (ed. G. Steinacher), Veröffentlichungen des Südtiroler Landesarchivs, 22, Bozen 2006, 33-58.

\section{LABANCA 2007}

Nicola Labanca, Oltremare. Storia dell'espansione coloniale italiana, Storica paperbacks, 31, Bologna 2007.

\section{LATZEL 1997}

Klaus Latzel, "Vom Kriegserlebnis zur Kriegserfahrung. Theoretische und methodische Überlegungen zur erfahrungsgeschichtlichen Untersuchung von Feldpostbriefen," Militärgeschichtliche Mitteilungen, 56, Potsdam 1997, 1-30.

\section{LECHNER 2005}

Stefan Lechner, "Die Eroberung der Fremdstämmigen": Provinzfaschismus in Südtirol 1921-1926, Veröffentlichungen des Südtiroler Landesarchivs, 20, Innsbruck 2005. 
MARTIN 1933

Carl Martin, Kurze Zusammenstellung über die Italienische Armee und die faschistische Nationalmiliz, Berlin 1933.

\section{MATTIOLI 2005}

Aram Mattioli, Experimentierfeld der Gewalt: Der Abessinienkrieg und seine internationale Bedeutung 1935-1941. Mit einem Vorwort von Angelo Del Boca, Kultur - Philosophie - Geschichte. Reihe des Kulturwissenschaftlichen Instituts Luzern, 3, Zürich 2005.

MÜNS 2010

Heike Müns, "Essen und Trinkenals Bekenntnis: Heimat - kulturelle Identität - Alltagserfahrung," in: Esskultur und kulturelle Identität: Ethnologische Nahrungsforschung im östlichen Europa (eds. H. Kalinke, K. Roth and T. Weger), Schriften des Bundesinstituts für Kultur und Geschichte der Deutschen im östlichen Europa, 40, Oldenburg 2010, 1126.

\section{OHNEWEIN 2006}

Thomas Ohnewein, "Südtiroler in Abessinien - Statistisches Datenmaterial," in: Zwischen Duce und Negus. Südtirol und der Abessinienkrieg 1935-1941 (ed. G. Steinacher), Veröffentlichungen des Südtiroler Landesarchivs, 22, Bozen 2006, 269-272.

\section{ORLANDI CONTUCCI 2011}

Antonio Orlandi Contucci (ed.), Passato d'Africa. La Guerra d'Etiopia nel diario di Goffredo Orlandi Contucci, Collona di studi diplomatici. Storia, memorie, saggi, 31, Catanzaro 2011.

\section{PALLAVER 2011}

Günther Pallaver, "Die Option im Jahr 1939: Rahmenbedingungen, Ablauf und Folgen," in: Deutsche! Hitler verkaufteuch! Das Erbe von Option und Weltkrieg in Südtirol (eds. G. Pallaver and L. Steurer), Bozen 2011, 13-34.

\section{PERGHER 2007}

Roberta Pergher, A Tale of Two Borders: Settlement and National Transformation in Libya and South Tyrol under Fascism, Ph.D. diss., University of Michigan 2007.

\section{PERGHER 2009}

Roberta Pergher, "Entering the Race: Fascism and the Boundaries of Italianness," in: Italian Politics and Society, 68, Carlisle 2009, 17-29. 


\section{PERGHER 2012}

Roberta Pergher, "Staging the Nation in Fascist Italy's 'New Provinces,'" in: Austrian History Yearbook, 43, Cambridge 2012, 98-115.

\section{PERGHER 2015}

Roberta Pergher, "Italy's Colonial Past," in: Routledge Handbook of Contemporary Italy: History, Politics, and Society (eds. A. Mammone, E. G. Parini and G. A. Veltri), New York 2015, 327-337.

\section{SAID 1981}

Edward Said, Orientalismus (tr. Liliane Weissberg), Frankfurt am Main et al. 1981.

\section{SCHULZE 1996}

Winfried Schulze, "Ego-Dokumente: Annäherungan den Menschen in der Geschichte? Vorüberlegungenfür die Tagung 'Ego-Dokumente,'” in: EgoDokumente. Annäherungan den Menschen in der Geschichte. Selbstzeugnisse der Neuzeit, 2 (ed. W. Schulze), Berlin 1996, 11-30.

\section{STEFANI 2003}

Giulietta Stefani, "Maschi in Colonia. Gli italiani in Etiopia," in: Genesis, II/2, Roma 2003, 33-52.

STEINACHER ET AL. 2006

Gerald Steinacher and Ulrich Beuttler, "Aus der Sicht des Soldaten: Fotoalben von Südtiroler Kriegsteilnehmern," in: Zwischen Duce und Negus: Südtirol und der Abessinienkrieg 1935-1941 (ed. Gerald Steinacher), Veröffentlichungen des Südtiroler Landesarchivs, 22, Bozen 2006, 87-194.

\section{STEININGER 1997}

Rolf Steininger, Südtirol im 20. Jahrhundert: Vom Leben und Überlebeneiner Minderheit, Innsbruck et al. 1997.

\section{STIEGLER 2015}

Bernd Stiegler, Theorien der Literatur- und Kulturwissenschaften. Eine Einführung, Paderborn 2015.

\section{ÜBEREGGER 1996}

Oswald Überegger, Freienfeld unterm Liktorenbündel: Eine Fallstudiezur Geschichte der Südtiroler Gemeindenunter dem Faschismus, Innsbruck 1996.

\section{VERDORFER 1990}

Martha Verdorfer, Zweierlei Faschismus: Alltagserfahrungen in Südtirol 1918-1945, Österreichische Texte zur Gesellschaftskritik, 27, Wien 1990. 
162 |

WISTHALER 2011

Sigrid Wisthaler, Karl Außerhofer - Das Kriegstagebuch eines Soldaten im Ersten Weltkrieg, alpine space - man \& environment, 8, Innsbruck 2011.

WURZER 2016

Markus Wurzer, "Nachts hörten wir Hyänen und Schakale heulen." Das

Tagebuch eines Südtiroler aus dem Italienisch-abessinischer Krieg 1935-

1936, Erfahren-Erinnern-Bewahren, 6, Innsbruck 2016. 